\title{
First report of Rhizoctonia solani affecting Prunus rootstock 'Garnem'
}

\author{
Noura Jemai $^{1} \cdot$ Samia Gargouri ${ }^{1} \cdot$ Mohamed Fakhri Ksouri $^{1} \cdot$ Kaouther Ben Mahmoud ${ }^{1} \cdot$ Ahmed Jemmali $^{1}$
}

Published online: 28 February 2019

(C) Società Italiana di Patologia Vegetale (S.I.Pa.V.) 2019

During winter 2016 , mortality of nearly $25 \%$ of in vitro plantlets of 'Garnem' rootstock (Prunus amygdalus $\times$ Prunus persica) was observed in a commercial nursery in Tunisia. Plantlets exhibited water-soaked lesions at the crown and roots, girdling the stem and collapsing the whole plants in a few days. 'Garnem' stems ( 25 plants) with typical symptoms were collected and rinsed with tap water. The margin between healthy and diseased tissue was cut into $0.5 \mathrm{~cm}$ pieces, surface sterilized with alcohol $\left(70^{\circ}\right)$, rinsed in sterile water and incubated on $1 / 4$ potato dextrose agar (PDA) at $25{ }^{\circ} \mathrm{C}$. Pure cultures were identified as Rhizoctonia solani on the basis of morphological features including right-angled branching of brown hyphae and the presence of sclerotia (Sneh et al. 1991). The internal transcribed spacer (ITS) region of two representative isolates was amplified with ITS1/ITS4 and sequenced (White et al. 1990). The sequences were analyzed using BLAST against GenBank database. The sequences were $98.7 \%$ identical to AG 1-IC isolate in GenBank (DQ279032) (González et al. 2016). The sequences were deposited in GenBank as KY964496 and KY964499. Pathogenicity test of the two isolates was conducted on 96 potted healthy plantlets of 'Garnem' rootstock, in a culture room at $25 \pm 2{ }^{\circ} \mathrm{C}$ and
$80 \%$ RH. A total of 36 plants / isolate were inoculated by placing one colonized oat grain with each of the two isolates next to the crown. Non inoculated plants served as control. After four days, typical Rhizoctonia stem lesions were observed in $83 \%$ of the inoculated plants and $R$. solani was successfully re-isolated from symptomatic tissues. To our knowledge, this is the first report of $R$. solani AG 1-IC on Prunus 'Garnem' rootstock nursery in Tunisia.

Publisher's note Springer Nature remains neutral with regard to jurisdictional claims in published maps and institutional affiliations.

\section{References}

González D, Rodriguez-Carres M, Boekhout T, Stalpers J, Kuramae EE, Nakatani AK, Vilgalys R, Cubeta MA (2016) Phylogenetic relationships of Rhizoctonia fungi within the Cantharellales. Fungal Biol 120(4):603-619

Sneh B, Burpee L, Ogoshi A (1991) Identification of Rhizoctonia species. The American Phytopathological Society, St. Paul

White TJ, Bruns T, Lee S, Taylor JW (1990) Amplification and direct sequencing of fungal ribosomal RNA genes for phylogenetics. Pp. 315-322 in: PCR protocols: a guide to methods and applications. Academic Press, Inc., New York

Noura Jemai

jemainoura92@gmail.com

1 Department of plant protection, National Institute of Agronomic Research of Tunisia, University of Carthage, Hedi Karray Street, 2049 Ariana, Tunisia 